\title{
Some aspects of cycle variability at the Diesel engine fuelled with animal fats
}

\author{
Adrian Nicolici ${ }^{1}$, Constantin Pană ${ }^{1}$, Niculae Negurescu ${ }^{1}$, Alexandru Cernat ${ }^{1}$, and Cristian \\ Nuţu ${ }^{1}$ \\ ${ }^{1}$ University Politehnica of Bucharest, Termothechnics, Engines, Thermal Equipments, and \\ Refrigeration Instalations Department, Bucharest, Romania
}

\begin{abstract}
The progressive diminution of the oil reserves all over the world highlights the necessity of using alternative fuels derived from durable renewable resource. The use of the alternative fuels represents a viable solution to reduce the pollutant emissions and to replace fossil fuels. Thus, a viable solution is the use of the animal fats in mixture with the diesel fuel at the diesel engines. A D2156 MTN8 diesel engine was firstly fuelled with diesel fuel and then with different blends of diesel fuel-animal fats $(5 \%$ and $10 \%$ animal fats content). In the paper are presented some results of the experimental investigations of engine fuelled with preheated animal fats. The raw animal fats effects on the combustion process and on the pollutant emissions at different engine loads and $1450 \mathrm{rev} / \mathrm{min}$ engine speed are showed. The engine cycle variability increases at the animal fats content increase. The cycle variability for maximum pressure, maximum pressure angle and indicated mean effective pressure is analysed. The cycle variability coefficients values don't exceed the recommended values of the standard diesel engine.
\end{abstract}

\section{Introduction}

Starting with the end of year 2014, the European Union commissioned and funded a research study named Ecofys were the use of animal fats as alternative fuel for power stations or for diesel engines is presented with great perspectives for emissions reduction of pollutant substances and greenhouse gases (GHG). Also, the advantage of a lower price comparative to vegetable oils is presented and analysed in the report [1], [2].

Due to low operating costs and high efficiency in use, durability and reliability are the most important demands for diesel engines that equip heavy duty vehicles which make them to be in common currency all over the world. Regarding the worldwide use of diesel engines due to its advantages the pollution impact on environment must be taking into consideration [3], [4], [5]. Worldwide, in recent years, many drastic measures for reduction of pollutant emissions with negative effects on health and the environment have been imposed. Many research programs have been developed to study the possibilities for

\footnotetext{
${ }^{1}$ Corresponding author: Alexandru Cernat : cernatt@gmail.com
} 
reducing of the pollutant emissions from combustion gases and of new control technologies of pollutant emissions, [3], [4], [5], [6], [7], [8], [9], [10].

These important aspects and issues represent an important topic of discussion at the 2015 United Nations Climate Change Conference (COP 21 or CMP 11), conference which was held in Paris. In this context, according to some researchers, important efforts are being made in order to limit the GHG emissions to zero in 2030-2050, [3].

On the other hand, the reduction of oil reserves around the world highlights the necessity of alternative energy use, an energy obtained from sustainable and renewable resources, and implementation of new technologies for energy use, [4], [6], [7], [8], [9], [10], [11], [12], [13].

Over the past decades, the number of automotives has been greatly increased the pollution emissions level being also increased especially in the urban areas. To combat this issue, the city of Oslo, the capital of Norway, has been set to become the first big clean city, free of pollutant emissions. Since 1960, in certain cities of Denmark, the circulation of pollutant vehicles fuelled by classic fuels is forbidden, but since then various alternative solutions have being adopted for the automotives traffic in these cities, [5].

The use of animal fats in blend with diesel fuel requires preheating of animal fats at a temperature higher than $40{ }^{\circ} \mathrm{C}$. If the temperature drops below this limit, the unsaturated fatty acids in the animal fats begin the solidification process in the fuel circuit, the risk of components clogging being present. At this temperature, the blend becomes homogeneous and it is also necessary to shake it to avoid shearing because of the density differences, [6], [12], [14], [15].

In the table 1 some of the physic-chemical properties of diesel fuel and animal fats are presented:

Table 1: The physic-chemical properties of diesel fuel and animal fats, [4], [6], [12]

\begin{tabular}{|c|c|c|}
\hline $\begin{array}{l}\text { Specific properties of the } \\
\text { fuels }\end{array}$ & Diesel Fuel & Animal Fat \\
\hline Density $\left[\mathrm{kg} / \mathrm{m}^{3}\right]$ & 849 & 920 \\
\hline Viscosity at $40^{\circ} \mathrm{C}\left[\mathrm{mm}^{2} / \mathrm{s}\right]$ & 2.96 & 4.8 \\
\hline Thick point $\left[{ }^{\circ} \mathrm{C}\right]$ & -12 & 6 \\
\hline Ignition point $\left[{ }^{\circ} \mathrm{C}\right]$ & 74 & 170 \\
\hline Boiling point $\left[{ }^{\circ} \mathrm{C}\right]$ & 191 & 344 \\
\hline Sulphur [\% m] & 0.036 & 0 \\
\hline Cetane number, CN [-] & 49.2 & 56 \\
\hline Low heating value, Hi & & \\
\hline MJ/kg] & 42.9 & 39.77 \\
\hline Carbon [\%] & 85.7 & 76.43 \\
\hline Hydrogen [\%] & 13.3 & 12.59 \\
\hline Oxygen [\%] & 1.0 & 10.98 \\
\hline
\end{tabular}

In the paper are presented some cyclic variability aspects of in-cylinder combustion process in a D2156-MTN8 diesel engine fuelled with animal fats-diesel fuel blends.

\section{Methodology}

The experimental investigations were carried on a truck diesel engine, type D2156 MTN8, 6 cylinders turbocharged, with $10.35 \mathrm{dm}^{3}$ displacement and compression ratio of 17.5:1, which develops a power of $188 \mathrm{~kW}$ and a maximum torque of $890 \mathrm{Nm}$. In order to setup the baseline of the experimental research, the engine was fuelled with only diesel fuel, all the experimental data's being registered. After baseline setup the diesel engine was fuelled with different animal fats-diesel fuel blends, the experimental procedure of data's acquisition 
being repeated in terms of maintaining the engine power at the same value recorded at classic fuelling operation. Preheated animal fats are blended with diesel fuel in proportions of $5(\%)_{\mathrm{v}}$ and $10(\%)_{\mathrm{v}}$, the final fuel blends being heated to $40{ }^{\circ} \mathrm{C}$. The experimental investigations were carried out at the regimes of $40 \%, 55 \%$ and $70 \%$ engine loads and speed of $1450 \mathrm{rev} / \mathrm{min}$, the injection timing being maintained constant at the reference value of $22{ }^{\circ} \mathrm{CA}$.

The test bed is equipped with specific experimental equipments used for measuring and control processes, the main components being: pressure transducer, incremental speed transducer, intake air flow meters for inlet air and fuels, data acquisition system, exhaust gas analyser, thermo-resistances and thermocouples for engine fluids temperature monitoring. The figure 1 illustrates the design of the experimental test bed.

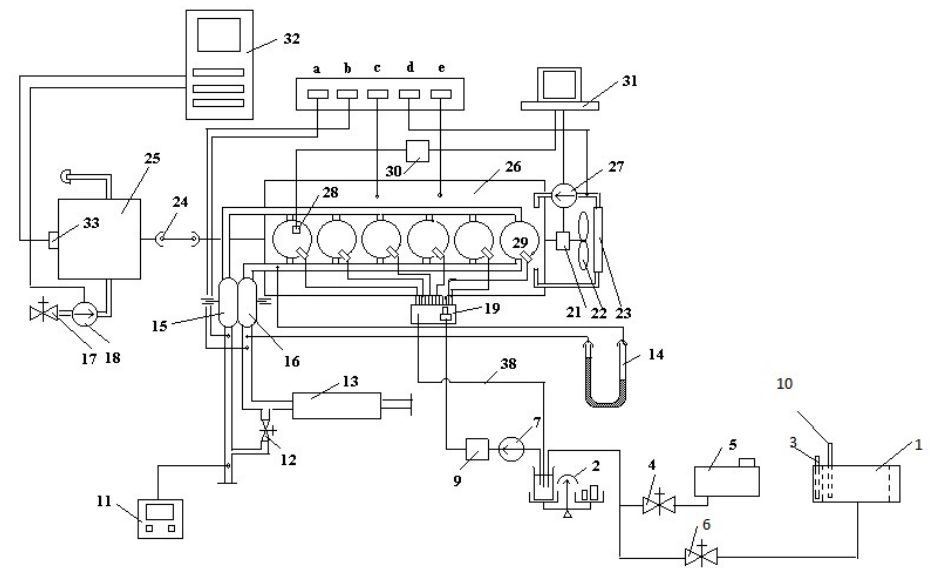

Fig. 1. The experimental test bed.

The main components of the experimental test bed are:

1. diesel fuel-animal fats blends tank; 2. fuel flow meter; 3. preheating electrical resistance; 4. diesel fuel valve; 5. diesel fuel tank; 6. animal fats-diesel fuel blends valve; 7. fuel pump; 9. fuel filter; 10. animal fats-diesel fuel blends thermometer; 11. AVL DiCom 4000 gas analyzer; 12. EGR valve; 13. Meriam air flow meter; 14. differential gauge for intake pressure measuring; 15-16. Holset Group turbo-supercharger; 17. dyno cooling water tap; 18. dyno cooling water pump; 19. fuel injection pump; 21. Kubler's incremental speed transducer; 22. fan; 23. engine cooling radiator; 24.coupling shaft; 25. Hoffman electric dyno; 26. diesel engine type D2156 MTN8; 27. engine cooling system pump; 28. incylinder Kistler piezoelectric pressure transducer; 29. diesel injector; 30. Kistler electric charge amplifier; 31. AVL Indicom data acquisition system; 32. dyno control cabinet; 33. dyno power cell; 38. fuel return pipeline; Shimaden SR indicators for temperatures of: a) exhaust gases, b) inlet air, c) engine oil, d) engine coolant and e) electronic indicator of engine oil pressure.

As research methodology, for each fuel blend and operating regime, a number of 100 consecutive combustion cycles were recorded by AVL data acquisition system. These cycles were further used to evaluate the indicated mean effective pressure (IMEP), the maximum pressure $\left(\mathrm{p}_{\max }\right)$ and the angle of maximum pressure $\left(\alpha_{\mathrm{pmax}}\right)$ for classic fuelling and for animal fats-diesel fuel fuelling. In order to determine the influence of the substitute ratio of diesel fuel by animal fats on the combustion cyclic variability the coefficients of 
variation for the indicated mean effective pressure, the maximum pressure and angle of maximum pressure were calculated.

The form of the cyclic variability coefficient, $\mathrm{COV}$, reflects the ratio of the standard deviation, $\sigma_{a}$, to the mean, $a_{\text {mean }}$, for a set of 100 measured cycles, as the following relation shows [7]:

$$
\operatorname{COV}_{a}=\frac{\sigma_{a}}{a_{\text {mean }}} \cdot 100
$$

where ' $a$ '' represents the studied parameter (IMEP, $\mathrm{p}_{\max }$ and $\alpha_{\mathrm{pmax}}$ ) [7], [8], [9].

The coefficient of cyclic variability for maximum pressure $\mathrm{COV}_{\mathrm{pmax}}$ is useful to study cyclic variability during the first phase of combustion. The cyclic variability coefficient of the indicated mean effective pressure, $\mathrm{COV}_{\mathrm{IMEP}}$, reflects the engine operation stability and shows the global engine response to the variability of the combustion process. As a result of the current experimental research, a stable operation of the diesel engine is ensured when the values of the cyclic variability coefficients are below $10 \%,[7]$. This study will show, comparatively to classic fuelling, if the fuelling with animal fats-diesel fuel blends can assure a normal engine operation so that normal drive-ability of the truck being achieved also for animal fats fuel blends.

\section{Results}

The maximum value of the substitution ratio, $\mathrm{x}_{\mathrm{c}}$, can be established in accordance with the values of $\mathrm{COV}_{\text {IMEP }}$ and $\mathrm{COV}_{\mathrm{pmax}}$.

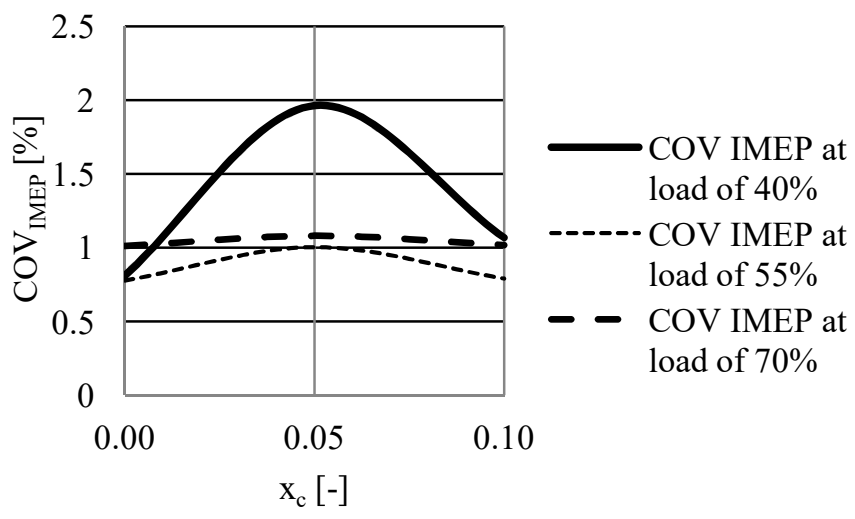

Fig. 2. The $\mathrm{COV}_{\mathrm{IMEP}}$ versus substitute ratio values.

For all engine loads regimes, $40 \%, 55 \%$ and $70 \%$, the $\mathrm{COV}_{\text {IMEP }}$ value starts to rise once with the increase of the substitute ratio comparative to classic fuelling as figure 2 shows. For the low load regime of $40 \%$ the COV increase is more significant comparative to others loads regimes, the maximum value of $\sim 2 \%$ being registered for $5 \%$ animal fats-diesel fuel blend, but don't exceed the $10 \%$ limit value. For $10 \%$ animal fats-diesel fuel blends the $\mathrm{COV}_{\text {IMEP }}$ decreases and remains above values recorded for diesel fuelling. Once with the rise of engine load the influence of animal fats percent in blend with diesel fuel is not so significant, the combustion process being more stable versus low loads operation. At high 
load, $70 \%$, the combustion variability is not significantly affected by animal fats use, the values of $\mathrm{COV}_{\text {IMEP }}$ having a very low variation versus diesel fuelling.

A similar variation is registered also for the values of $\mathrm{COV}_{\mathrm{pmax}}$ calculated for all engine loads regimes, figures 3 . At $40 \%$ engine load the maximum value does not exceed $2.33 \%$ and it is not necessary to limits the substitution ratio because the limit of $10 \%$ is not exceed it. At $55 \%$ and $70 \%$ engine loads the increases are reduced the maximum values remaining in the area of values registered for diesel fuelling, $x_{c}=0$.

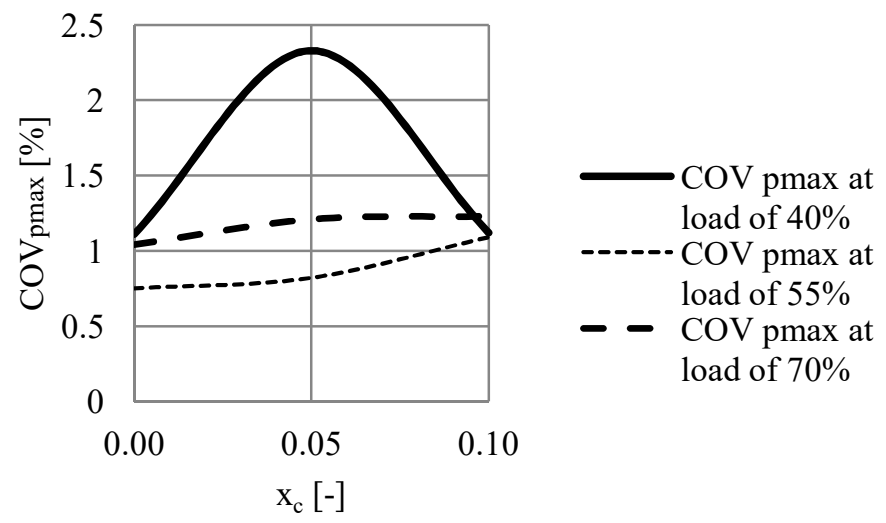

Fig. 3. The $\mathrm{COV}_{\text {pmax }}$ versus substitute ratio values.

For $\mathrm{x}_{\mathrm{c}}=5 \%$ the increasing tendency in variation of the COV for IMEP and maximum pressure are in correlation and can be taken into consideration when $5(\%)_{\mathrm{v}}$ animal fats is used in blend with diesel fuel. Also, the increase tendency for $\mathrm{COV}_{\mathrm{pmax}}$ for $10(\%)_{\mathrm{v}}$ animal fats-diesel fuel is present.

At the increase of the substitution ratio the angle of maximum pressure, $\alpha_{\text {pmax }}$, occurs later on the combustion cycle because the increase of animal fats content leads to the aggravation of fuel atomization and autoignition delay increase. The angles of maximum pressure are: $13.4^{\circ} \mathrm{CA}$ at $\mathrm{x}_{\mathrm{c}}=0 ; 11.8^{\circ} \mathrm{CA}$ at $\mathrm{x}_{\mathrm{c}}=5 ; 12.8^{\circ} \mathrm{CA}$ at $\mathrm{x}_{\mathrm{c}}=10$ for $40 \%$ engine load; $13^{\circ} \mathrm{CA}$ at $\mathrm{x}_{\mathrm{c}}=0 ; 11.9^{\circ} \mathrm{CA}$ at $\mathrm{x}_{\mathrm{c}}=5 ; 12.1^{\circ} \mathrm{CA}$ at $\mathrm{x}_{\mathrm{c}}=10$ for $55 \%$ engine load and finally, $14^{\circ} \mathrm{CA}$ at $\mathrm{x}_{\mathrm{c}}=0 ; 13^{\circ} \mathrm{CA}$ at $\mathrm{x}_{\mathrm{c}}=5 ; 12.9^{\circ} \mathrm{CA}$ for $70 \%$ engine load, figure 4 .

The use of animal fats in small percents leads to the reduction of the dispersion between angles of maximum pressure values. The increased trend of COV values for $\alpha_{\text {pmax }}$ for substitution ratios bigger than $\mathrm{x}_{\mathrm{c}}=5 \%$ is in correlation with the slightly increased values for $\mathrm{COV}_{\text {IMEP }}$ and $\mathrm{COV}_{\text {pmax }}$ at $55 \%$ and $70 \%$ engine loads. Thus, at animal fats use in blend with diesel fuel the combustion variability is increased for low loads regime, the higher loads easily allowing the use of higher animal fat quantities without affecting the engine operating stability.

Thus, the slightly increase of cycle dispersion between values of IMEP and maximum pressure, but it reduce the dispersion between the cycle moment when the maximum pressure occurs per cycle. Practically, at animal fats use the combustion variability during the rapid phase of combustion is slightly increased, but dispersion between its durations from cycle to cycle tends to be reduced. 


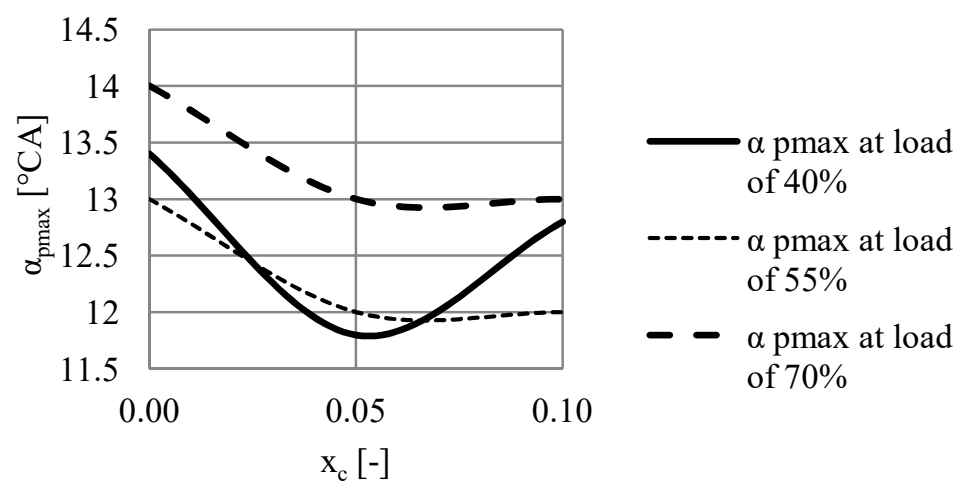

Fig.4. The maximum pressure angle versus substitute ratio values.

The $\mathrm{NO}_{\mathrm{x}}$ formation is associated with high temperature zones corresponding to preformed mixtures. Figure 5 shows that at the $40 \%$ engine load, the $\mathrm{NO}_{\mathrm{x}}$ emissions level is decreased with $20.4 \%$ for $5(\%)_{\mathrm{v}}$ animal fat in blend with diesel and decreases with $20.8 \%$ for $10(\%)_{\mathrm{v}}$ animal fats percent. The decrease of $\mathrm{NO}_{\mathrm{x}}$ emissions level is explained by the reduction of the quantity of preformed mixture resulting from the aggravation of fuel atomization at animal fats use, which leads to lower combustion temperature compared to diesel fuel. The $\mathrm{NO}_{\mathrm{x}}$ formation is influenced by temperature, time and mixture dosage, the increase of combustion gas temperature and combustion time leads to raised temperatures which favour the $\mathrm{NO}_{\mathrm{x}}$ formation reactions [10]. A lower caloric power of animal fats versus diesel fuel leads also to the reduction of the combustion temperature per cycle at animal fats use and to the reduction of $\mathrm{NO}_{\mathrm{x}}$ emission level, at high engine loads. At low engine loads, the reduction of diesel fuel dose at rise of animal fats content in blends leads to the reduction of the gases combustion temperature and autoignition delay increase.

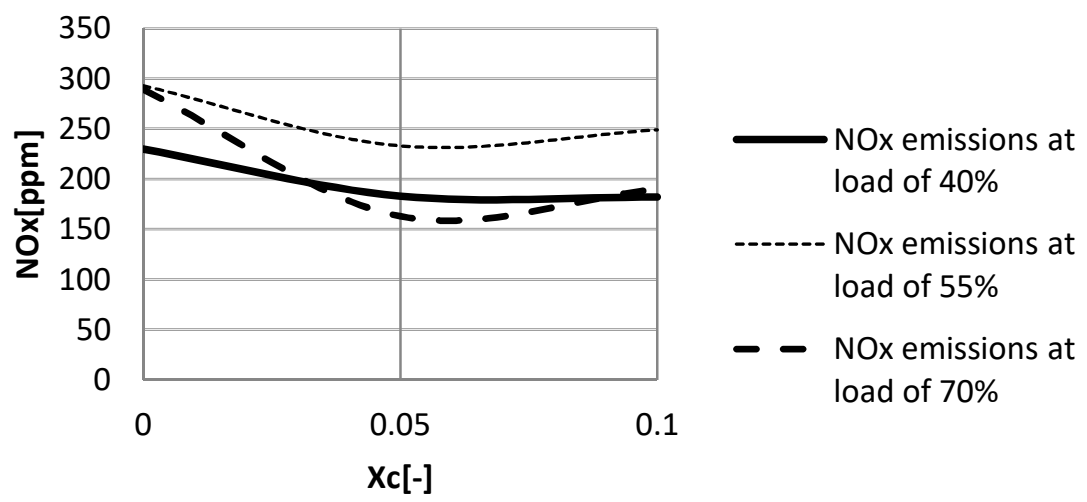

Fig 5. The $\mathrm{NO}_{\mathrm{x}}$ emissions level versus different substitute ratio values.

The increasing tendency of $\mathrm{NO}_{\mathrm{x}}$ emissions level at same engine loads can be limited by injection timing tune. The $\mathrm{NO}_{\mathrm{x}}$ emission decreases are correlated with the increased stability of premixed phase of combustion, with lower values for $\mathrm{COV}_{\alpha \mathrm{pmax}}$, figure 4.

Versus diesel fuel fuelling the smoke emission level starts to decrease once with the rise of animal fat content in blend with diesel fuel, for all engine loads regimes, figure 6 . 
The reduction of smoke emission level can be explained by lower carbon content and higher oxygen content in the final fuels blend at the increase of animal fats content, due to the fact that animal fats contain more oxygen and less carbon comparative to diesel fuel.

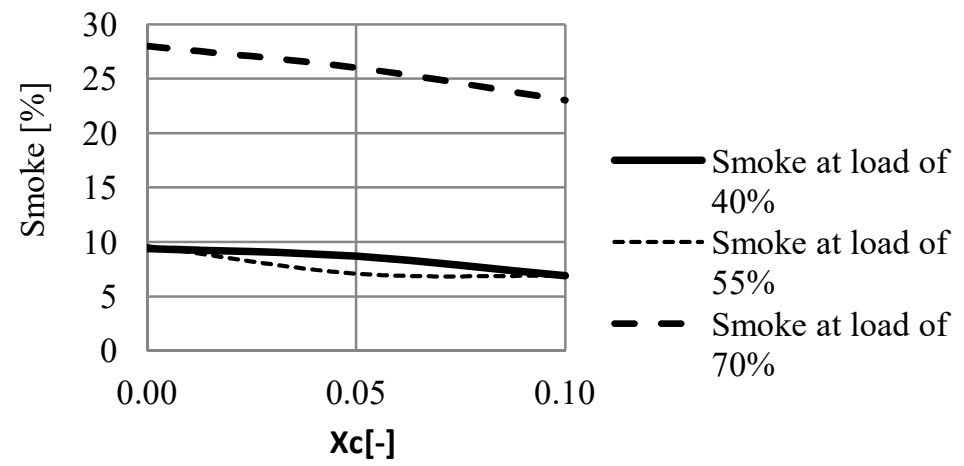

Fig. 6. The smoke emission level versus different substitute ratio values.

Thus, at $70 \%$ engine load the use of $10(\%)_{\mathrm{v}}$ animal fats-diesel fuel blends leads to the reduction of smoke opacity with $14 \%$ and to the decrease of smoke number by $35 \%$, figure 6. At $40 \%$ engine load the opacity is decreased by $25 \%$ and the smoke number is reduced by $34 \%$, for $10(\%)_{\mathrm{v}}$ animal fats-diesel fuel blend. At $55 \%$ engine load the reduction are similar.

\section{Conclusions}

The study of combustion cycle variability at animal fats-diesel fuel blends use at diesel engine leads to the main following conclusions:

- the values for $\mathrm{COV}_{\text {pmax }}$ and $\mathrm{COV}_{\text {IMEP }}$ slightly rise comparative to diesel fuelling, but the calculated values don't exceed 3\%, being under the 10\% limit, the normal diesel engine operation being assured at animal fats use and the limitation of the substitute ratio is not necessary from this point of view

- the values of $C O V \alpha_{\text {pmax }}$ are reduced at animal fats use, the cyclic dispersion between angles of maximum pressure being lower comparative to diesel fuel use

- regarding the variability of the combustion process, the higher engine loads easily accept $10(\%)_{\mathrm{v}}$ animal fats in final fuel blend comparative to low load regime, the COV values for maximum pressure and IMEP being smaller for 55\%-70\% engine loads versus values registered for $40 \%$ engine load

- the $\mathrm{NO}_{\mathrm{x}}$ emissions level decreases with almost $20 \%$ for $40 \%$ and $70 \%$ engine loads due to reduction of the cycle combustion temperature in correlation with a smaller caloric power of animal fats versus diesel fuel

- the smoke emission levels are reduced at animal fats use, with $14 \%$ at high engine loads and with $25 \%$ respectively at low engine loads due to the rise of oxygen content and decrease of carbon content in the fuel blends once with the rise of animal fats content

- the use of animal fats-diesel fuel blends in order to improve the diesel engine pollutant performance can be assured in terms of a normal combustion variability which assures the normal drive ability of the automotive, the fuelling method being easier to apply due to the fact that it doesn't require important engine design modification. 
The authors address special thanks to AVL GmbH Graz Austria for providing the necessary equipments. This work was supported by a grant of the Romanian Ministery of Research and Innovation, CCCDI - UEFISCDI, project number PN-III-P1-1.2-PCCDI2017-0404 / 31PCCDI/2018, within PNCDI III

\section{References}

[1] C. Chudziak and S. Haye (E4tech), Final report Task 4a of ENER/C1/2013-412, Indirect emissions from rendered animal fats used for biodiesel, date: 21 June (2016)

[2] Al. Cernat, C. Pana, N. Negurescu, Cr. Nutu, A. Nicolici, Proceedings of the $4^{\text {th }}$ International Congress of Automotive and Transport Engineering (AMMA), Butanol effects on the fuelled diesel engine operation with preheated diesel animal fuel blends, ISBN 9783-319-94408-1, (2018)

[3] İ.A. Reşitoğlu, K. Altinişik, A. Keskin, Clean Techn Environ Policy, The pollutant emissions from diesel-engine vehicles and exhaust after treatment systems, 17: 15. https://doi.org/10.1007/s10098-014-0793-9, (2015)

[4] M. G. Popa, C. Pana, N. Negurescu, Matrixrom, Bucharest, Diesel engines. Processes, (2003)

[5] V. Emil Lucian, Biocombustibili-Ghid de obtinere a energiei din deseuri, Ed. Universitara Bucuresti, ISBN 978-606-28-0439-8, (2016)

[6] S. Alonso J. Gobernado Arribas S. Miñambr, International J. Energ. and Environ Eng, Study of combustion in residential oil burning equipment of animal by-products and derived products not intended for human consumption, Vol. 4, pp 1-13, (2013)

[7] J. B. Heywood, editor: McGraw-Hill Book Company New York, Internal Combustion Engines Fundamentals, (1988)

[8] A. C. Polk, C. D. Carpenter, K. K. Srinivasan, et al., Fuel, An investigation of dieselignited propane dual fuel combustion in a heavy-duty diesel engine, 132, pp. 135-148, (2014)

[9] B. Ashok, S. Denis, C. Ramesh, C., Kumar, Alex Eng J, LPG diesel dual fuel engine A critical review, 54, pp. 105-126, (2015)

[10] RK. Srinivasa, A. Ramakrishna, PV.Rao, Int Jl of Mech Eng and Techn, Performance and emission characteristics of DI-CI diesel engine with preheated chicken fat biodiesel, volume 4, issue 3, (2013)

[11] M. S. Kumar, A. Kerihuel, J. Bellettre and M.Tazerout, J of Eng from Gas Turb and Pow, A Comparative Study of Different Methods of Using Animal Fat as a Fuel in a Compression Ignition Engine, 128, (2006)

[12] T. Mata, A. Mendes, N. Caetano A. Martins, Ch Eng Trans, Properties and sustainability of biodiesel from animal fats and fish oil, volume 38:175-80, (2014)

[13] A. Kumar, J. Kerihuel, M. Bellettre, M. Tazerout, M. Senthyl, Ren En, The use of preheated animal fat as fuel in a compression ignition engine, voulme 30 (issue 9), pp.1443-56, (2005)

[14] M. Czechlowski, W. Golimowsski, T. Sek J. Szymanowicz, Mainte and reli Eksploatacja I Niezawodnosc, Exhaust opacity in a diesel engine powered with animal fats,- 17, Pp. 49-53, (2015)

[15] J. Alonso, A. Minambres,G. Arriba, J of Comb, Study of Thermal Energy Production by Combustion of Lard and Diesel Mixtures, Volume 2012, ID 912581, pp. 1-9, (2012) 